\title{
Aspects of the history of Parkinson's disease
}

\author{
J M S PEARCE
}

From the Department of Neurology and Parkinson's disease Clinic, Hull Royal Infirmary, Hull, UK

\section{ASPECTS OF THE HISTORY OF PARKINSON'S DISEASE}

\section{Aspects of the history of Parkinson's disease}

Before James Parkinson's classic' "An Essay on the Shaking Palsy" (1817) ancient books recorded many types of paralytic disorders and tremors. None fully described the distinctive features of the syndrome which so justly perpetuates Parkinson's name.

His essay (fig 1) mentioned the earlier writings of Juncker who distinguished tremors, either "Activesudden affections of the mind, terror, anger or, Passive -dependant on debilitating causes such as advanced age, palsy etc." He credited Sylvius de la Boe for showing the important difference between rest (tremor coactus) and action tremor in 1680. Parkinson cites Sauvages "the tremulous parts leap, and as it were vibrate, even when supported: whilst every other tremor, he observes, ceases, when the voluntary exertion for moving the limb stops . . but returns when we will the limb to move;" $\mathrm{He}$ also referred to van Swieten (1749) who had made similar observations about rest tremor. Sauvages had described the festihant gait which "I think cannot be more fitly named than hastening or hurrying Scelotyrbe (scelotyrbem festinantem, seu festiniam)", as did Gaubius some ten years earlier (1758).

\section{James Parkinson}

This brief essay can neither replace nor do justice to the scholarly writings devoted to James Parkinson, his life and work.

The reader is referred to McMenemey's essay, ${ }^{2}$ Gardner-Thorpe's introduction to the reprint of The Shaking Palsy ${ }^{3}$ and to Kenneth Tyler's comprehensive review. ${ }^{4}$ Cleevely and Cooper ${ }^{5}$ outline his work as a social reformer and geologist and append an extensive bibliography.

James was born on 11 April 1755, the first child of Mary and John Parkinson. John was an apothecary and surgeon who lived and worked at 1 Hoxton Square in the district of Shoreditch in London. He

Address for reprint requests: $\operatorname{Dr} J$ M S Pearce, Department of Neurology, Hull Royal Infirmary, Hull HU3 2JZ, UK.
AN

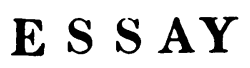

ON THE

\section{S H A K I N G PA LSY.}

Figure 1

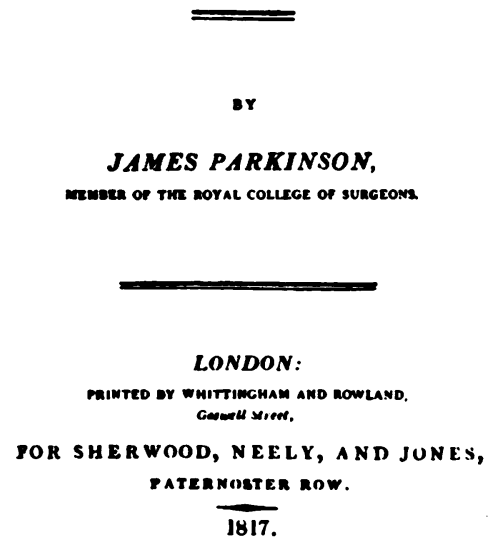

was Anatomical Warden of the Surgeon's Company which had replaced the Barber's Company in 1745 and was succeeded by the Royal College of Surgeons in 1800. In addition to his substantial medical contributions James was variously described as a radical political pamphleteer (under the pseudonym of "Old Hubert"), a pacifist, an agitator for parliamentary reform, a member of secret societies and, a campaigner for social welfare. Interestingly, no verified portrait of him exists.

His writing was prolific. His first work was a critical account of medical practice Observations on Dr Hugh Smith's Philosophy of Physic etc in 1780. 
The text of the Memorial reads:

\section{IN PIAM MEMORIAM}

JAMES PARKINSON

OF HOXTON SURGEON AND APOTHECARY

DIPLOMATE OF THE COMPANY OF SURGEONS

MEMBER AND THE FIRST HONORARY MEDALLIST

OF THE ROYAL COLLEGE OF SURGEONS

IN HIS "ESSAY ON THE SHAKING PALSY"

HE FIRST DESCRIBED THE DISEASE

SINCE KNOWN BY HIS NAME

FOUNDER MEMBER OF THE GEOLOGICAL SOCIETY OF LONDON

AND AUTHOR OF "ORGANIC REMAINS OF A FORMER WORLD"

HONORARY MEDALLIST OF THE ROYAL HUMANE SOCIETY POLITICAL AND SOCIAL REFORMER

BORN AT I HOXTON SOUARE II APRIL 1755

WHERE HE PRACTISED FOR FORTY YEARS DIED AT 3 PLEASANT ROW HOXTON

21 DECEMBER 1824

BAPTIZED AND MARRIED IN THIS CHURCH AND BURIED IN THE CHURCHYARD

A LIFE LONG WORSHIPER AT THE PARISH CHURCH

\section{ERECTED BY THE NURSING STAFF OF ST LEONARD'S HOSPITAL}

Figure 2

His most famous book was a palaeontologoical study Organic Remains of a Former World in 3 vols (1804-1811) which ran to three editions. His medical works included: some accounts of the effects of lightning, a case of diseased vermiform appendix (possibly the first account of appendicitis), typhoid fever, hydrophobia, hints for the improvement of trusses, gout, and the Essay on the Shaking Palsy. A crinoid Apiocrinuxs parkinsoni, a gastropod Rostellaria parkinsoni, an ammonite Parkinsonia parkinsoni and a stemless palm Nipa parkinsoni are other commemorative tokens ${ }^{5}$ to this phenomenal and scholarly scientist.

James married Mary Dale in May 1781 and they had six children; two died in infancy, one son John qualified in medicine and shared his practice. James was afflicted with gout for many years, but is said to have died of a stroke ${ }^{3}$ on 21 December 1824 . He was baptised, married and was finally buried in St Leonard's church where a marble plaque (fig 2) was unveiled in September 1955.

\section{The shaking palsy}

The essay spans 66 pages and five chapters. A preface offers the reader a conciliatory explanation for a "publication in which mere conjecture takes the place of experiment". "It has not yet obtained a place in the classification of the nosologists ...; whilst the unhappy sufferer has considered it an evil, from the domination of which he had no prospect of
$\mathbf{A N}$

\section{E S S A Y}

on rac

\section{SHAKING PALSY.}

\section{CHAPTER I.}

DEFINITION-HISTORY-ILLUSTRATIVE CASES.

SHAKING PALSY. (Paralysis Agitans.)

Involuntary tremulous motion, with lessened muscular power, in parts not in action and even when supported: with a propensity to bend the trunk forward, and to pass from a walking to a running pace: the senses and intellects being uninjured.

Figure 3

escape." He stressed the need for "a continuance of observation of the same case, or at least a correct history of its symptoms, even for several years. He regretted that "the disease had escaped particular notice and the task of ascertaining its nature by anatomical investigation." He hoped pathologists might "be excited to extend their researches to this malady."

Parkinson's inquiring mind shines throughout the essay in an array of acute clinical observations and inferences. His descriptions leave one in doubt as to whether he examined his patients in the conventional fashion, but the sharpness of his eye and his qualities as a naturalist are self evident. As in his quixotic excursions into contemporary politics and the righting of social ills, the essay betrays his deep compassion and humanitarian qualities.

Chapter 1 opens with his classic summary (fig 3). The words shaking palsy had been used before, but imprecisely; tremors had been described by Galen, Juncker (tremores paralytoidei), and by Cullen. "So slight and nearly imperceptible are the inroads of this malady, and so extremely slow its progress . . that the patient cannot recall the onset. The first symptoms perceived are, a slight sense of weakness with a proneness to trembling ... most commonly in one of the hands and arms." " $\ldots$ in less than twelvemonths or more, the morbid influence is felt in some other part." After a few more months the patient is found to be less strict than usual in preserving an upright posture." 
“...As the disease proceeds ... the hand fails to answer the dictates of the will. Walking becomes a task which cannot be performed without considerable attention. ... care is necessary to prevent frequent falls." "The disease proceeds, difficulties increase: writing can now be hardly at all accomplished; and reading, from the tremulous motion, is accomplished with some difficulty." Later, "the propensity to lean forward becomes invincible, and the patient is forced to step on the toes and fore part of the feet, ... irresistibly impelled to take much quicker and shorter steps, and thereby to adopt unwillingly a running pace." ..."The bowels which had all along been torpid, the expulsion of faeces requiring mechanical aid." Finally "his words are now scarcely intelligible ... no longer able to feed himself ... saliva is continually draining from the mouth, mixed with particles of food he is no longer able to clear from the inside of the mouth." Terminally he describes sleepy exhaustion with incontinence and loss of articulation.

Parkinson then provides six beautifully illustrative case histories of men aged 50,62, 65, 55, 72 years and a gentleman, the particulars of which could not be obtained ("the lamented subject of which was only seen at a distance'). It is curious that no women were described.

The symptoms-tremor coactus and scelotyrbe festinans, their nature and the opinions of preceding writers are considered in chapter 2 (vide supra). Differential diagnosis is considered in the third chapter. Parkinson emphasised that this "disease does not accord with any which are marked in the systematic arrangements of the nosologists." He refers to palsy consequent to compression of the brain, or exhaustion of that organ. He decries the use of the term "shaking palsy" in convulsive affections, including those of a lady with what we would now call ballistic attacks, and convulsions. Another case cited might be an example of torsion dystonia. He finally describes "the trembling consequent to the indulgence in the drinking of spirituous liquors and the immoderate employment of tea and coffee-tremor temulentus."

The proximate and remote causes are considered in chapter 4 along with illustrative cases. " $A$ diseased state of the medulla spinalis, in that part which is contained in the canal, formed by the superior cervical vertebrae, and extending, as the disease proceeds, to the medulla oblongata" is the proximate cause. Parkinson again expresses his uncertainty, lacking anatomical observations, but postulates injury to the medulla or theca related to the mobility of the cervical spine "which must render it and the contained parts, liable to injury from sudden distortions." His cases in this chapter are described for analogy; he realises they differ substantially from paralysis agitans (a term used by Parkinson in his title page, but not initiated by Marshall Hall, as is often stated). A man with paralysis and venereal infection, palsies occasioned by injury to the brain, medulla and upper cord, and Pott's carious disease of the spine are mentioned. This chapter fully portrays the state of knowledge, the limitations of medical practice and the grave difficulties which beset physicians of the day.

Similarly, chapter 5 devoted to means of cure, shows us how frustrating attempts at treatment were at that time. Optimism prevails however, "there appears to be sufficient reason for hoping that some remedial process may ere long be discovered." $\mathrm{He}$ discusses in turn: "blood taken from the upper part of the neck, ... vesicatories applied to the same part and a purulent discharge obtained by use of the Sabine Liniment;". Later he remarks "Until we are better informed regarding the nature of this disease, the employment of internal medicines is scarcely warrantable;".

This classic and exemplary essay ends by generously extolling the virtues of his colleagues professional ardour and devotion and "the benefits bestowed on mankind by the labours of a Morgagni, Hunter, or Baillie."

\section{Later developments}

The essay was well received and cited in Cooke' Treatise on Nervous Disease, ${ }^{6}$ and in Marshall Hall' celebrated Lectures on the Nervous System ${ }^{7}$ and by Robert Bentley Todd (of Todd's palsy) in a paper ane in his clinical lectures on paralysis. ${ }^{8}$ Marshall Hall had access to necropsy on a 28 year old patient with "hemiParkinsonism" and concluded that the disease was related to a lesion of the corpora quadrigemina; he noted a resemblance to tremor mercurialis. By the mid 1850 s the disease was well established and described in the works of Stokes and Robert Graves; ${ }^{4}$ and, it is confounded with a description of action tremor in Romberg's Lehrbuch.' But little new was added.

Trousseau's 15th Lecture on Clinical Medicine ${ }^{10}$ was on senile trembling and paralysis agitans. He described rigidity, a sign Parkinson did not pay attention to, and, he explained the scelotyrbe festinans "as his centre of gravity is thus displaced, he is obliged to run after himself, as it were, so that he keeps trotting and hopping on." Trousseau also described the progressive slowing of repeated hand opening, the first clear account of bradykinesia. Although James Parkinson had said "the senses and intellects being uninjured", Trousseau was aware that "the intellect ... gets weakened at last; the patient loses his memory, and his friends notice soon that his mind is not as clear prococious caducity sets in." Trousseau was a realist he had, he said, not cured a single patient with medicaments; pneumonia was the common exitus 
lethalis, but he was not aware of any necropsy performed in France.

Charcot, Vulpian and Ordenstein wrote extensively on the Salpetrière experience which is crystallised ${ }^{11}$ in Lecture 5 of Charcot's Lecons sur les malades du système nerveux (1877). Their views leaned heavily on Todd's work. Cold, damp and "emotions morales vives" were held important. Charcot described the affliction as one of the over 50 s and classed it as a neurosis that is, with no proper structural cause. Tremor was the cardinal symptom "limited at first to one member, then little by little becoming generalised." Later "almost pathognomonic, the patient closes the fingers on the thumb as though in the act of spinning wool ... or crumbling bread ..." The movements are slow and seem feeble, although dynamometrical experiments prove that this diminution is not real." $\mathrm{He}$ partly ascribed the weakness to "the rigidity which prevails in the muscles."

Charcot recognised "a tendency to propulsion and retropulsion ... the individual is unable to stop-being apparently forced to follow a flying centre of gravity." He referred to the "peculiar attitude of the body and its members, a fixed look, and immobile features." He analysed the writing, noting the tremulous fine upstrokes when the down-stroke was firm and relatively normal. Speech was "slow, jerky and short of phrase ... jolted out as it were, like an inexperienced rider on horseback, when the animal is trotting." Parkinson had not commented on the rigidity of neck, trunk and extremities; Charcot elucidated these signs and said Parkinson had overlooked them. Bradykinesia was not dependent on rigidity "dependent neither on the existence of tremors, nor on that of muscular rigidity." He shrewdly anticipated modern concepts of the movement disorder: a lapse of time between the thought and the act. Terminally "the mind becomes clouded and memory is lost." Tremor faded late in the disease and the final event, as Trousseau had noted, was often pneumonia. His pathological studies added little, but therapeutically he noted the palliative effect of hyoscyamine, the precursor of other belladonna alkaloids.

In Pathogenie et Symptoms de la Maladie de Parkinson in 1895 , Brissaud ${ }^{12}$ made significant contributions. He remarked on speech as "murmured an interminable littany", the voice weakened without intonation. "The eyelids were rigid, fashion of trembling, ... pupils stenosed and rigid." "At the idea of movement, tremor worsened, with movement itself, tremor ceased." The synchrony of tremor led him to favour a central origin of the disease. He also observed "psychic disorders" the same repugnance to emit their ideas as to move their limbs. Paying attention to a crucial paper of Blocq and Marinesco in which hemiplegic Parkinsonism resulted from a tuberculoma of the contralateral inferior peduncle, destroying the locus niger, he remarked "a lesion of the locus niger could very well be the anatomical basis of Parkinson's disease." At that time nothing was known of the structure or physiology of the substantia nigra and this was a remarkable and prophetic comment of Brissaud's.

Gowers characteristically surveyed ${ }^{13}$ the scene in masterly fashion, reviewing 80 patients of his own. He noted a male preponderance, age of onset $50-60$ years in half the cases and a hereditary influence (now disputed) in $15 \%$. Like Charcot he had seldom seen tremor in the face or head. The gait, speech, writing, and the propensity for mental weakness, loss of memory and a tendency to delusions were clearly enunciated. A mixture of "arsenic, Indian hemp (cannabis), sometimes combined with opium" were advocated.

\section{Pathology}

Parkinson's disease was considered a syndrome of the motor cortex by Gowers and his predecessors, the function and pathophysiology of the basal ganglia being then obscure. Tretiakoff in 1919 examined the brains of nine Parkinsonian patients and noted ${ }^{14}$ a variety of degenerative lesions, but pointed out reduced numbers of pigmented cells in the locus niger which he related to disorder of the muscular tone in Parkinson's disease. He also found peculiar concentric inclusions in the cytoplasm of these nigral cells which had been described by FW Lewy in 1913. A more complete study of the mesencephalon and its neuropathology formed the basis of a classic paper by Foix and Nicolesco ${ }^{15}$ in 1925 , by which time the essential anatomical substrate, which so frustratingly had eluded James Parkinson, was more or less complete.

The pandemic of encephalitis lethargica of von Economo between 1917 and 1926 left in its wake a new variety of disease: post-encephalitic Parkinsonism. This was the first of the symptomatic causes of the syndrome recognised, but the clinical features and natural history were substantially different from paralysis agitans. Rare sporadic cases are still described, and its historical importance may be as an indicator of the possibility of slow viral infections of the brain, their epidemiology and sequelae. Critchley had attempted to separate "arteriosclerotic Parkinsonism" from paralysis agitans; and a galaxy of striatal Parkinson-like syndromes, bearing a variety of eponyms, have been recognised and demarcated from idiopathic paralysis agitans.

\section{Recent advances}

The disease was a commonplace in clinical practice between the Great Wars. My undergraduate textbook (Davidson, 3rd edn, 1956) mentions tinct belladonna, 
tinct stramonium and hyoscine hydrobromide and "newer synthetic preparations Artane, Lysivane and Pipanol." Great strides have taken place since this time, and since they are well known, I shall mention them only in outline.

Irving Cooper's serendipitous damage to the anterior choroidal artery whilst ligating an aneurysm in a Parkinsonian subject spectacularly controlled contralateral signs; this led to deliberate surgical lesions first in the globus pallidus, then in ventrolateral nucleus of thalamus, effected by the ingenious stereotactic devices of the 1950 s with which I failed to cope as a neurosurgical house surgeon. Chemopallidectomy employed alcohol and other destructive agents; later thermal and cryogenic physical methods were used. Unilateral tremor and rigidity were often abolished with striking benefit, but the central features affecting speech, gait, posture and balance were unaffected, and sometimes worsened by these procedures.

The levodopa story, starting in the laboratories of Ehringer and Hornykiewicz in 1960 is too well known to merit repetition here. The late George Cotzias showed that large doses of oral d-1-dopa were clinically highly effective, but I well remember the vomiting, fainting and delay of two to three months before a stable response was obtained. The pure l-isomer lessened toxicity and the addition of a dopa-decarboxylase inhibitor was an important step forward. Bob Schwab's discovery of amantadine and the advent of dopamine agonists followed. But the most significant recent advance has been the experimental model afforded by the (1-methyl-4-phenyl-1,2,3,6-tetrahydropyridine) MPTP contaminants. This was discovered in 1976 when a 23 year old American addict took a shortcut to synthesising his own pethidine analogue. One byproduct was MPTP ${ }^{16}$ causing severe and pure Parkinsonism on the third day, which responded to levodopa till his suicide 18 months later. The current excitement concerning foetal nigral transplants awaits the validation of time and future research.

David Marsden has in the last 20 years been the preeminent figure in Parkinson's disease research. Preeminent, not only in Great Britain, but throughout Europe and North America. His enormous personal industry, organising capacity and eloquence are now near legendary. Of the recent advances, none has escaped the golden touch of the Marsden research unit at Kings, and more recently at Queen Square. We hope these recent investigative problems and ultimately their solution will be the objects of future histories.

\section{References}

1 Parkinson J. An Essay on the Shaking Palsy. London: Sherwood, Neely, and Jones 1817.
2 McMenemey WH. James Parkinson (1755-1824). A biographical essay. In: Critchley M, ed. James Parkinson. London: MacMillan, 1955.

3 Gardner-Thorpe C. James Parkinson. Exeter: A Wheaton \& Co, 1987.

4 Tyler KL. A History of Parkinson's Disease. In: WC Woller, ed. Handbook of Parkinson's Disease. New York, Basel: Marcel Dekker Inc. 1987:1-34.

5 Cleevely RJ, Cooper J. James Parkinson (1755-1824). A significant English 18th Century Doctor and Fossil Collector. Leiden. Tertiary Research. 1987;8(4): 133-45.

6 Cooke R. History of the method of cure of the various species of palsy, p.207, vol 2, part 1, In: A treatise of Nervous Diseases. London: Longman, 1821.

7 Hall Marshall. On the Diseases and Derangements of the Nervous System. London: Balliere, 1841.

8 Todd RB. Certain Diseases of the Brain and other Affections of the Nervous System. Philadelphia, Lindsay \& Blakiston, 1855.

9 Romberg M. Lehrbuch der Nervenkrankheriten des Menschen. Berlin: A Duncker, 1840-6.

10 Trousseau A. Lecture XV: Senile trembling and Paralysis Agitans. In: Lectures on Clinical Medicine delivered at the Hotel-Dieu, Paris. trans: PV Bazire. London: New Sydenham Society, 1868.

11 Charcot JM. On Paralysis Agitans (lecture V). In: 0 Lectures on the Diseases of the Nervous System. pp. 129-156. trans: G Sigerson. London: New Sydenham Society, 1877.

12 Brissaud E. Vingt-Deuxieme Lecon: Pathogenie et symptoms de la maladie de Parkinson. pp. 488-501. In: Merge $\mathrm{H}$, ed. Leçons sur les maladies nerveuses (Salpetriere 1893-1894). Paris: G Masson, 1895.

13 Gowers WR. A Manual of Diseases of the Nervous System. 2nd ed. pp. 589-607. London: Churchill, 1888.

14 Tretiakoff C. Contributions a l'étude de L'anatomie pathologique du locus niger de soemmering avec quelques deductions relatives a la pathogenie des troubles de tonus musculaire et de la maladie de Parkinson. Paris: Thesis, 1919.

15 Foix C, Nicolesco J. Anatomie cerebrale: les Noyaux Gris Centraux et la Region Mesencephalo-soux-optique. Paris: Masson, 1925.

16 Langston WJ. Mechanism of MPTP toxicity: more answers, more questions. Trends in Pharmacological Sciences 1985;6:375-8.

Additional bibliography

Rowntree LG. James Parkinson. Bulletin of the Johns Hopkins Hospital 1912;23:33-45.

Morris AD. James Parkinson. Born April 11, 1755. Lancet 1955;269:761-3.

Knight DM. Chemistry in Palaeontology: The work of James Parkinson (1755-1824). Ambyx 1974;21:78-85.

Eyles JM. James Parkinson (1755-1824). Nature 1955; 176:580-1.

Jefferson M. James Parkinson (1755-1824). Br Med J 1973; 2:601-4. 